\title{
ECOCIDE CRIMES \& OMNIBUS LAW: REVIEW OF INTERNATIONAL LAW AND ITS IMPLICATIONS ON INDONESIA LAW
}

\author{
Satria Unggul Wicaksana Prakasa \\ Faculty of Law Universitas Muhammadiyah Surabaya \\ satria@fh.um-surabaya.ac.id
}

\begin{abstract}
Omnibus Law which seeks to simplify 79 laws and 1288 articles. The Omnibus Law, some of the articles have the potential to remove the protection of rights, obsess over the human rights of citizens, particularly about civil and political, economic, social, and cultural rights, and concerning law enforcement for environmental destroyers who are weak. The research used socio-legal research methods. The results of the study are the limitations in prosecuting perpetrators of ecocide crimes only in war crimes, making it difficult to hold responsibility for crimes committed, both against individuals and multinational/transnational corporations. Omnibus Law has enormous potential to perpetuate the practice of ecocide crime systematically both in the political, legal, and socio-economic, cultural aspects. Thus, there is no reason to strengthen that the Omnibus Law is favoring environmental destruction, and perpetuating the practice of impunity for perpetrators of environmental damage crimes.
\end{abstract}

\section{Keywords: Ecoside Crimes, Law Enforcement, Omnibus Law}

Abstrak: RUU Omnibus Law Cipta Kerja yang berupaya menyederhanakan 79 UU dan 1.288 Pasal. RUU Omnibus Law Cipta Kerja, sejumlah pasal berpotensi menghapus perlindungan hak, merepsesi HAM warga negara, khususnya terkait dengan hak-hak sipil dan politik dan ekonomi, sosial dan budaya. Serta berkenaan dengan penegakkan hukum bagi perusak lingkungan yang lemah. Metode penelitian yang digunakan adalah menggunakan metode penelitian sosio-legal. Hasil penelitian adalah Keterbatasan dalam penuntutan pelaku kejahatan ekosida hanya pada kejahatan perang membuat sulitnya meminta pertanggungjawaban atas kejahatan yang dilakukan, baik terhadap individu maupun korporasi multinasional/transnasional. RUU Omnibus Law Cipta Kerja menjadi potensi yang sangat besar untuk melanggengkan praktik kejahatan ekosida yang secara sistematis baik dalam aspek politik hukum, maupun sosial ekonomi, kebudayaan. Sehingga, tidak ada alasan yang menguatkan bahwa RUU Omnibus Law Cipta Kerja ini justru memihak pada pengrusakan lingkungan, serta melanggengkan praktik impunitas bagi pelaku kejahatan kerusakan lingkungan.

\section{Keywords: Kejahatan Ekosida, Penegakkan Hukum, RUU Omnibus Law}

\section{INTRODUCTION}

At the last time, the discussion of Omnibus Law as an effort to simplify the rule of law or commonly called the Omnibus Law became a pro and contra discourse of Omnibus Law in the community. The concept of Omnibus Law is often used in various law countries that use the common law system in making legal regulations. The Omnibus is expected to improve overlapping regulations, especially related to investment issues, one of which is in the forestry sector. So if the birth of the bill is passed will be an improvement to the rules of Law No. 41/1999 concerning Forestry, Law No.32 / 2009 concerning Environmental Protection and Management (Perlindungan dan Pengelolaaan Lingkungan Hidup/ PPLH), and Law No.5 / 1960 concerning Basic Regulations on Agrarian Principles (UndangUndang Pokok Agraria/ UUPA) (Mongabay.com, 2020).

The Omnibus Law which seeks to simplify 79 laws and 1288 Articles, various civil society groups, environmental organizations, human rights organizations, indigenous movement, social workers, and others joined the protest. Some things that are considered to support systematic environmental damage such as not requiring an AMDAL include an AMDAL Commission that is not formed, then B3 waste which dumps B3 waste may be disposed of by individuals and companies in rivers, the sea, and continues to the land without having permission from the government. As well as very crucial matters relating to the government's strict liability to ensnare corporate the forest and the land burning regulated in article 88 of Law No.32 / 2009, individuals and corporations do not need to prove that how forest land is on fire and who is burning (Mongabay.com, 2020).

In the context of widespread criticism of the Omnibus Law, several articles have the potential to remove the protection of rights, obsess over the human rights of citizens, specifically related to civil and 
political and economic, social and cultural rights, and concerning law enforcement for destroyers of the weak environment (Wiratraman, Omnibus Law dan HAM, 2020). On a more specific spectrum, if the problem of environmental damage is continuous to be left without maintaining ecological principles, and prioritizes the investment approach and protects oligarchs and corporations that fall into the category of environmentally destructive mafias.

Some coalitions of civil society in some cases of environmental destruction crimes have commenced equalizing these crimes with the humanity crimes. The Lapindo mudflow case in Sidoarjo, for example, the overflow of wells from PT. Lapindo Brantas oil drilling was categorized as a human rights violation. In several other cases such as the 2015 forest and land fires and the construction of the 1990 Koto Panjang Riau Hydroelectric Power Plant. The alleged intentionally burned millions of hectares of forest, claimed livelihoods, caused respiratory diseases, and displaced tens of thousands of human settlements, and killed tiger and elephant habitats (Forestdigest.com, 2019).

Including, forest fires and land (kebakaran hutan dan lahan/ karhutla) that occurred at some point in the outermost, like in Riau, Sumatra, and at some point in Borneo, causing a haze of smoke that bothers millions of people in Southeast Asia, one of the countries affected are Malaysia and Singapore. The World Bank estimates that Indonesia will lose around 221 trillion rupiah in the forestry, agriculture, tourism, and other industries sectors. Fogs of smoke made hundreds of thousands of people sick in all affected areas. According to figures released by the Republic of Indonesia's Ministry of Environment and Forestry (KLHK), around 24 million hectares (ha) of the country's rainforest were destroyed between 1990 and 2015 (Prakasa, Merdeka dari Asap, 2019).

So that, not only the environment is structured, but there are joints of crimes against humanity that continue to expand. BNPB data as of 2018 said that in Indonesia 2,426 disasters occurred, of which $96.6 \%$ were hydrometeorological disasters, watershed damage, critical land damage rates, and various environmental damages that had a direct impact on climate change. The contribution of environmental damage in Indonesia has an impact on global environmental damage, currently, the human population in the world is around 7.6 billion, making 1 million species extinct in the last 50 years, the temperature of the earth rose 08, degrees Celsius in the last 200 years since industrialization began. The earth is headed for sporadic destruction and humans have intentionally committed mass destruction, not only for their species but also for the destruction of the earth itself (Forestdigest.com, 2019).

The term ecocide crime was first introduced during the war between Vietnam and the US between 1962-1971. The US military is believed to use chemicals sprayed from the air to destroy food crops, the aim being that the Viet Cong cube will soon lose the war in a hungry condition, also to clear natural forests and mangroves aimed at guerrillas feeling hungry. This concept in terms of international law is very rapidly developing, specifically related to corporate responsibility as perpetrators of eco-crime (M. Ridha Saleh, 2019).

Bringing together ecological crimes and genocide crimes as a new type of crime called ecocrimes, as well as their links to the Omnibus Law. This research will focus on two major issues which will be discussed next, namely: (1). How is the international legal mechanism between ecocide crimes and Omnibus Law? (2). What is the Indonesian legal mechanism regarding the recognition of ecocide crimes?

\section{RESEARCH METHODS}

The identification carried out in the socio-legal study is not limited to the text, but also a deepening of the context, which includes all processes, for example from 'law-making' to 'implementation of law'. The label of socio-legal studies has gradually become a general term that encompasses a group of disciplines that apply a social scientific perspective to legal studies, including legal sociology, legal anthropology, legal history, psychology and law, justice political study, and comparative science (Tamanaha, 1997).

The socio-legal approach is a combination of approaches within the social sciences, including politics, economics, culture, history, anthropology, communication, and many other sciences, combined with approaches known in law, such as learning about principles, doctrines, and hierarchy of laws. The socio-legal approach is thus the single concept for this combination. Thus, the legal analysis conducted has a broad and interdisciplinary perspective in describing the issues raised in this study (Wiratraman \& Putro, Tantangan Metode Penelitian Interdisipliner Dalam Pendidikan Hukum Indonesia, 2019). So that, the main problems raised in this legal research can be answered comprehensively, specifically the link between the ecocide crime and the emphasis on international law and its implications for the legal system in Indonesia. 


\section{RESULT AND DISCUSSION}

\section{The Concept of Ecocide Crimes}

Conceptually, eco-crime in this era of globalization is the impact of imperialism and capitalism. The production base state which later established multinational and transnational corporations and established an industrialization agenda that affected poor countries, the neo-liberal ideology has invested a matter of privilege, even negated the sustainability of development and ecological principles. The impact is, increasingly neglected matters relating to ecological sustainability, corporations are left to damage the environment under the pretext of facilitating the investment climate. Inequality in socioeconomic conditions is exacerbated by environmental damage making ecocide crime highly relevant to global poverty and suffering (Broswimmer, 2002).

In the context of free trade, the joints of the preservation of the environment are negligible, multinational corporations / transnational in its business activities are reluctant to meet the obligations to respect and measure to protect and provide for an effective remedy for perpetrators of environmental damage, at the same time the rights of affected communities are often neglected, even access to mechanisms of responsibility and accountability is very difficult to do (Prakasa, Perdagangan Internasional Dan Ham: Relasinya Dengan Sustainable Development, 2017).

Some concepts refer to eco-crime as not only an international crime, the conceptualization of eco-crime has moved from conventional Genocide crime regulated in the 1948 UN Convention on AntiGenocide, eco-crime has become a new crime (Short, 2016), where the perpetrators are not only the state but also the perpetrators' Corporations thus need recognition and conceptualization in the concept of ecocrime to destroy certain groups indirectly through means of environmental destruction (Docker, 2004).

The link between environmental crime, genocide, and multinational corporations in accountability before international law. Under the UN mechanism, various institutions are carried out, including the SubCommission, including the Legal Committee under the General Assembly and the International Law Commission trying to make a definition between crime and its relation to environmental destruction, several elements of crime, including formal and material aspects to hold accountable eco-crimes discussed for more than 40 years at the international level (Anja Gauger, 2013) ${ }^{1}$

The discussion of ecocide crime is closely related to the values of humanitarian law, its investment model is based on an assessment of environmental conditions, and is supported by the geopolitical situation and supports market liberalization and also large-scale nuclear development in several countries, making the situation of handling ecocide crime will be very severe without the support of commitment global politics and strong cooperation in handling and stopping the practice of impunity for these crimes (Austin \& E.Bruch, 2000).

The linkage between environmental crime, genocide, corporate responsibility, and the mechanism of accountability before international law are elements that can describe the relationship with eco-crime as a whole concept, for later steps based both on international law and the Indonesian legal system

\section{a. Environmental Crimes}

Environmental crime becomes a complex problem for all countries in the world, a multidimensional approach to see the structure, culture, and ecological issues becomes something that needs to be looked at more deeply, its challenges to environmental fighters whose impact is also on society, environment, and the development sustainability is very hard (Navas, Mingorria, \& Aguilar-González, 2018) Groups of people who defend their ecological rights vis a vis with attacks on the state and oligarchic groups which then give birth to authoritarian practices and impunity for perpetrators.

The oligarchy group, which consists of government power that has the authority to grant permits and is supported by privileged investments to gain maximum profits without taking sides in preserving the environment makes natural resources a resource to perpetuate its power. In this context, in addition to the damaged environmental aspects, it is also exacerbated by the massive exploitation of natural resources, even if it must be protected by relevant legislation (A.Winters, 2012).

\footnotetext{
${ }^{1}$ Sub-Commission on Prevention of Discrimination and Protection of Minorities. Study of the Question of the Prevention and Punishment of the Crime of Genocide. Prepared by Mr. Nicodème Ruhashyankiko. 4 July 1978. E/CN.4/Sub.2/416. The Sub-Commission on Prevention of Discrimination and Protection of Minorities undertakes studies and makes recommendations to the Commission concerning the prevention of discrimination against racial, religious and linguistic minorities. Composed of 26 experts, the Sub-Commission meets each year for four weeks. It has working groups and established Special Rapporteurs to assist it with certain tasks. http://www.un.org/rights/dpi1774e.htm
} 
To minimize environmental crimes, the state is obliged to make regulations that guarantee compliance and implement sanctions for perpetrators of environmental destruction. National legal mechanisms should be the basic norm to ensure that aspects of sustainable development are realized. This becomes the concentration explained in the 1992 Rio de Janeiro Convention so that the process for the legal mechanism can be effective starting from national law. If then national law is unable and unwilling to resolve national law crimes, only then international environmental law mechanisms can be effectively implemented through bilateral/multilateral agreements or joint investigations through various agreed legal mechanisms (due diligence of law) (Sands, 2003).

The process of prosecuting environmental crimes driven by oligarchs is difficult to be legally processed because of the reluctance to comply with the fulfillment of human rights, not buying commensurate compensation for the environmental damage caused, compensation for victims, participation in the recovery of the effects of environmental damage, health aspects, education, etc. that need strong human rights and socio-political legal approaches (Steady, 2009).

Therefore, there needs a comprehensive framework established by the state referring to international environmental law mechanisms to be effectively carried out with an integrated assessment model, between investment and the impact of degradation and environmental damage aimed at making the policies implemented aim to protect environmental sustainability and development sustainable, not create a policy paradigm that is governed by liberalization and free markets ( policy-based market-driven paradigm ) (Leichenko \& O’Brien, 2008).

\section{b. Genocide}

The term genocide crime was first introduced by Raphael Lemkin in his book "Nazi crimes in occupied Europe" in 1944 which later became the basis for the prosecution at the Nurenberg Military Court which was later recognized in the UN General Assembly Resolution (GA Res 96 (1)). In 1948, the 1948 Anti-Enoside Convention was agreed as an international rule to crack down on perpetrators of genocidal crimes. The weakness of the agreement is that there is no permanent international court that can try perpetrators of genocide before 1998. There are two ad hoc courts like the International Criminal Tribunal for Rwanda (ICTR) and the International Criminal Tribunal for ex-Yugoslavia (ICTY) (Robert Cyrer, 2012).

The Rome Statute of 1998 then provided an effective mechanism for convicting perpetrators of genocide in a permanent international court, the International Criminal Court. The element of genocide crime is regulated in Article 6 of the Rome Statute of 1998, namely:

For this Statute, 'genocide' means any of the following acts committed with intent to destroy, in whole or in part, a national, ethnical, racial, or religious group, as such:

(a) Killing members of the group;

(b) Causing serious bodily or mental harm to members of the group;

(c) Deliberately inflicted on the group conditions of life calculated to bring about its physical destruction in whole or in part;

(d) Imposing measures intended to prevent births within the group;

(e) Forcibly transferring children of the group to another group

In this context, according to William A. Schabas, the Genocide of the 3 other types of crimes are under the 1998 Rome Statute is on "destroying" ethnical, racial, national, and religious aspects The objects that are destroyed are: (1) physic; (2) biology/genetic; (3) culture, including ecosystems (A.Schabas, 2007). In this context, it is very clear then for perpetrators of crimes who intentionally intend to destroy a certain national, ethnic, racial, religious group either directly or indirectly, including its relation to efforts to destroy the ecosystem, they can be categorized as a genocide offender.

\section{c. Corporation as Ecocide Crime}

The presence of multinational/transnational corporations is greatly influenced by trade and investment liberalization which has implications for the establishment of companies in other countries (host countries). International law has regulations on the relationship between free trade and its relation to foreign investment (Trade-Related Investment Measures (TRIMs)). TRIMs are addressed by the World Trade Organization (WTO), a specialized UN body that handles free trade to prevent member countries from violating trade with the principle of national treatment. TRIMs also prohibit investment actions that result in the violation of trade principles set by the WTO (WTO, 2015).

At The UN Guiding Principles on Business and Human Rights (UNGP) through the UN Human Rights Council Resolution No. 17/4, signed on June 16, 2011, three basic principles of Business and Human 
Rights are: (1) Protect (the obligation of the state to protect); (2) Respect for the actions that may be posed by transnational corporations in its business activities; (3) Remedies (imposing sanctions) due to the impact of business activities, where when the transnational corporation establishes its company in a country is extra-territorial. (UN Office of The High Commissioner for Human Rights, 2014).

The recognition of multinational transnational corporations as subjects of international law is a debatable issue, the recognition of a subject of international law has an impact on corporate liability in its activities before international law (O.Adeola, 2000), especially in terms of environmental damage caused, namely the crime of eco-ides as an effect of corporation confession as subjects of international law signify acceptance of personality and responsibility in terms of the obligation to comply with and apply the principles of international law that apply universally (N.Shaw, 2008).

\section{d. Ecocide Accountability Mechanism in International Law}

In the material context of eco-crimes based on the Rome Statute of 1998 are indeed still attached to the types of war crimes regulated in Article 8 paragraph (iv) of the Rome Statute of 1998 which explains:

Intentionally launching an attack in the knowledge that such attack will cause incidental loss of life or injury to civilians or damage to civilian objects or widespread, long-term and severe damage to the natural environment which would be excessive to the concrete and direct overall military advantage anticipated;

In the case of international criminal liability under the Rome Statute of 1998, this is explained in Article 25 , specifically relating to individual liability, which explains that:

1. The Court shall have jurisdiction over natural persons under this Statute.

2. A person who commits a crime within the jurisdiction of the Court shall be individually responsible and liable for punishment under this Statute.

3. Under this Statute, a person shall be criminally responsible and liable for punishment for a crime within the jurisdiction of the Court if that person:

(a) Commits such a crime, whether as an individual, jointly with another or through another person, regardless of whether that other person is criminally responsible;

(b) Orders, solicits, or induces the commission of such a crime which occurs or is attempted;

(c) To facilitate the commission of such a crime, aids, abets, or otherwise assists in its commission or its attempted commission, including providing the means for its commission

(d) In any other way contributes to the commission or attempted commission of such a crime by a group of persons acting with a common purpose. Such contribution shall be intentional and shall either:

(i) Be made to further the criminal activity or criminal purpose of the group, where such activity or purpose involves the commission of a crime within the jurisdiction of the Court; or (ii) Be made in the knowledge of the intention of the group to commit the crime;

(e) In respect of the crime of genocide, directly and publicly incites others to commit genocide;

(f) Attempts to commit such a crime by taking action that commences its execution using a substantial step, but the crime does not occur because of circumstances independent of the person's intentions. However, a person who abandons the effort to commit the crime or otherwise prevents the completion of the crime shall not be liable for punishment under this Statute for the attempt to commit that crime if that person completely and voluntarily gave up the criminal purpose.

4. No provision in this Statute relating to individual criminal responsibility shall affect the responsibility of States under international law.

In the context of individual responsibility, this shows that the limitation in prosecuting perpetrators of ecocide crimes only in war crimes makes it difficult to hold accountable for crimes committed, both against individuals and multinational/transnational corporations. This is a real threat that requires international commitment in the amendment process of the Rome Statute of 1998 and strengthens the commitment of international politics to environmental preservation so that there is no impunity for perpetrators of eco-crime in the dimension of international law.

\section{Indonesian Legal Mechanisms in the Recognition of Ecocide Crimes}

Indonesia is a country with unclear legal regulations applied to perpetrators of eco-crimes. Concerning environmental damage can be seen in Chapter IX of Law No. 23 of 1997, which contains 
various provisions and criminal threats against perpetrators of acts that violate environmental legislation. An important aspect of this criminal provision is action and behavior considered to violate environmental protection. The criminal mechanism in environmental law regulates the mechanism of environmental destruction and pollution along with criminal sanctions for the act. Thus, all actions that pollute or damage the environment, if they are done intentionally can be considered a crime, especially environmental crime (Dermawan, 2006). The mechanism is trying to be weakened in the Omnibus Law.

Then, when referring to Law No.26 / 2000 concerning the Human Rights Court which regulates the mechanism of gross human rights crimes, there are no strict rules regarding eco-crimes. The context of gross human rights violations under Law No.26 / 2000 only regulates genocide crimes and crimes against humanity as regulated in Article 7, Article 8, and Article 9. The distortion of the meaning contained in Law No. 26/2000 causes Indonesia nowadays has not ratified the Rome Statute of 1998 so that the unilateral interpretation of Indonesia is a weakness in its enforcement of the perpetrators of ecocrimes.

Therefore, perpetrators of environmental crimes that have a systematic impact on environmental damage and systematically commit gross human rights violations should be punished effectively, both individual and corporate actors, including multinational/transnational corporations.

\section{CONCLUSION}

Limitation in prosecuting perpetrators of ecocide crimes only in war crimes makes it difficult to hold accountable for crimes committed, both against individuals and multinational/transnational corporations. This is a real threat that requires international commitment in the amendment process of the 1998 Rome Statute and strengthens international political commitment to environmental preservation so that the practice of impunity for eco-crime perpetrators does not occur in the dimension of international law.

The Omnibus Law creates a huge potential to perpetuate systematic practices of eco-crime both in the political, legal, and socio-economic, cultural aspects. Thus, there is no reason to strengthen that the Omnibus Law is favoring environmental destruction, and perpetuating the practice of impunity for perpetrators of environmental damage crimes.

\section{BIBLIOGRAPHY}

A.Schabas, W. (2007). An Introduction to the International Criminal Court (3rd ed.). Cambridge: Cambridge University Press.

A.Winters, J. (2012). Oligarchy (2nd ed.). Cambridge: Cambridge University Press.

Anja Gauger, e. (2013). The Ecocide Project: Ecocide is the missing 5th Crime Against Peace. London: Human Rights Consortium: School of the Advanced Study University of London.

Austin, J. E., \& E.Bruch, C. (2000). The Environmental Consequences of War: Legal, Economic, and Scientific Perspectives (1st ed.). Cambridge: Cambridge University Press.

Broswimmer, F. (2002). Ecocide: a Short History of the Mass Extinction of Species (1st ed.). London: Pluto Press.

Dermawan, M. K. (2006). Kejahatan Lingkungan: Suatu Tinjauan Kriminologi. Jurnal Masyarakat dan Budaya, 82(2), 97-120.

Docker, J. (2004). Raphael Lemkin's History of Genocide and Colonialism', Contribution for United States Holocaust Memorial Museum (1st ed.). Washington DC: Center for Advanced Holocaust Studies.

Forestdigest.com. (2019). Ekosida: Kejahatan Lingkungan yang Belum Diakui. Jakarta: Forest Digest.

Leichenko, R. M., \& O'Brien, K. L. (2008). Environmental Change and Globalization: Double Exposures (2nd ed.). Oxfordshire: Oxford University Press.

M. Ridha Saleh, e. (2019). Ecocide: Memutus Impunitas Korporasi (1st ed.). Jakarta: Walhi dan Yayasan TIFA.

Mongabay.com. (2020). Bisa Celakakan Lingkungan, Banyak Kalangan Protes RUU Omnibus Law. Jakarta: https://www.mongabay.co.id/2020/03/18/bisa-celakakan-lingkungan-banyak-kalanganprotes-ruu-omnibus-law/.

N.Shaw, M. (2008). International Law (6th ed.). Cambridge: Cambridge University Press.

Navas, G., Mingorria, S., \& Aguilar-González, B. (2018). Violence in environmental conflicts: the need for a multidimensional approach. Sustainability Science, 13(special issues The EJAtlas: Ecological Distribution Conflicts as Forces for Sustainability), 649-660. 
O.Adeola, F. (2000). Cross-National Environmental Injustice and Human Rights Issues. The American Behavioral Scientist; Jan 2000; 43, 4; Sociology Database, 43(4), 686.

Prakasa, S. U. (2017). Perdagangan Internasional Dan Ham: Relasinya Dengan Sustainable Development. Jurnal Hukum Novelty, 8(1), 36-53.

Prakasa, S. U. (2019). Merdeka dari Asap. Surabaya: https://www.harianbhirawa.co.id/merdeka-dariasap/.

Robert Cyrer, e. (2012). an Introduction to International Criminal Law and Procedure (1st ed.). Cambridge: Cambridge University Press.

Sands, P. (2003). Principles of International Environmental Law (2nd ed.). Cambridge: Cambridge University Press.

Short, D. (2016). Redefining Genocide: Settler Colonialism, Social Death and Ecocide (2nd ed.). London: Zed Books Ltd.

Steady, F. C. (2009). Environmental Justice in the New Millenium: Global Perspectives on Race, Ethnicity, and Human Rights (2nd ed.). New York: Palgrave MacMillan.

Tamanaha, B. Z. (1997). Realistic Socio-Legal Theory: Pragmatism and a Social Theory of Law (123127 ed.). Oxford: Clarendon Press.

UN Office of The High Commissioner for Human Rights. (2014). UN Guiding Principles on Business and Human Rights. New York: UN.

Wiratraman, H. P. (2020). Omnibus Law dan HAM. Surabaya: https://www.jawapos.com/opini/10/03/2020/omnibus-law-dan-ham/.

Wiratraman, H. P., \& Putro, W. D. (2019). Tantangan Metode Penelitian Interdisipliner Dalam Pendidikan Hukum Indonesia. Jurnal Mimbar Hukum, 31(3), 403-415.

WTO. (2015). Understanding the WTO (1st ed.). Geneva: WTO Publisher. 